\title{
A new host for Philornis torquans (Diptera, Muscidae) from the Brazilian Cerrado
}

\author{
Márcia Souto Couri ${ }^{1,5}$, Leandro Barbosa ${ }^{1,6}$, Miguel Ângelo Marini ${ }^{2}$, Charles Duca ${ }^{3}$ \& José Roberto Pujol-Luz ${ }^{4}$ \\ 1 Universidade Federal do Rio de Janeiro (UFRJ), Museu Nacional, Departamento de Entomologia, Laboratório de Diptera. Rio de Janeiro, RJ, Brasil. \\ ${ }^{2}$ Universidade de Brasília (UNB), Instituto de Ciências Biológicas (IB), Departamento de Zoologia, \\ Laboratório de Ecologia e Conservação de Aves. Brasília, DF, Brasil. ORCID: 0000-0002-7300-7321. E-mail: marini@unb.br \\ 3 Universidade Vila Velha (UVV), Laboratório de Ecologia de Populações e Conservação (LEPC). Vila Velha, ES, Brasil. \\ ORCID: 0000-0003-3903-8260. E-mail: cduca@uvv.br \\ ${ }^{4}$ Universidade de Braślia (UNB), Instituto de Ciências Biológicas (IB), Departamento de Zoologia, Laboratório de Entomologia. \\ Brasília, DF, Brasil. ORCID: 0000-0002-8621-4856. E-mail: jrpujolluz@gmail.com \\ ${ }^{5}$ ORCID: 0000-0002-5340-395X. E-mail: courimarcia@gmail.com \\ ${ }^{6}$ E-mail: leanbarbosa@gmail.com
}

\begin{abstract}
Philornis larvae and pupae were collected in nestlings of Neothraupis fasciata (Lichtenstein), the White-banded Tanager (Passeriformes, Thraupidae), in three breeding seasons, between 0ctober and November 2003-2005 in a reserve in central Brazil. Here, we present biological data, diagnosis to the recognition of the species and a key to the segregation of species occurring in the Cerrado. The larvae were intradermic in the nestlings and the pupae were collected in the nests after the birds have abandoned them. The immatures collected were taken to the laboratory and reared under laboratory conditions, until emergence. The species identified as Philornis torquans (Nielsen), is here firstly recorded from the Brazilian Cerrado, and firstly recorded its association with $N$. fasciata. With this record, the number of Philornis species occurring in the Cerrado rises to three.
\end{abstract}

Key-Words. Larvae; Cerrado vegetation; Myiasis; New record; Parasites.

\section{INTRODUCTION}

The association of Philornis Meinert (Diptera, Muscidae) larvae with at least 115 bird species, mostly in the Neotropics is well known (Dudaniec \& Kleindorfer, 2006). Philornis is distributed in Central and South America and south of the USA, with at least 50 species recorded so far (Carvalho et al., 2005).

The first apparent mentions to this association in Brazil seems to date to the 17th century, first in 1618 by A.F. Brandão in Cacicus cela (Linnaeus) (Passeriformes, Icteridae) in Pernambuco and then in 1648 by Georg Marcgrave, also in the northeastern of Brazil (Teixeira, 1999).

The larvae can be coprophagous in the nests, semi-hematophagous or intra-dermic hematophagous in the nestlings (Couri, 1984, 1985). However, there are only few records with intradermic larvae attacking adults. For example, breeding female of Thamnophillus palliatus (Lichtenstein) was parasitized with Philornis glaucinis Dodge \& Aitken larva (Mendonça \& Couri, 1999).

Because of the damage that Philornis larvae can cause to their hosts, the number of publications recording parasitized birds has also been increased. Despite all the importance of this relationship, the association is known only for about $40 \%$ of the Philornis species (Teixeira, 1999). Likewise, little is known about their biology and the real damage that they can cause to the nestlings, as even in severe infestations with a high number of subcutaneous larvae, the nestling can survive. The surviving nestlings often have deformed beaks, reduced growth rates, and anaemia and in some cases, mortality can reach $100 \%$ per nest (Fessl et al., 2001). Bulgarella et al. (2015) considered that the accidental introduction of Philornis downsi (Dodge \& Aitken) represents a threat to the conservation of birds in the Galapagos Islands, especially for endemic species. The authors also reported the parasitism of $P$. downsi in two hosts in mainland Ecuador - the Streak-headed Woodcreeper (Lepidocolaptes souleyetii) and the Fasciated Wren (Campylorhynchus fasciatus).

The first records of Philornis species to the Brazilian Cerrado were $P$. angustifrons and $P$. deceptivus Dodge \& Aitken, both subcutaneous parasites in nestlings of both Suiriri affinis (Burmeister) and S. islerorum Zimmer, Whittaker \& Oren (Passeriformes, Tyrannidae) (Higgins et al., 2005). Both host species are considered to be endemic to the Cerrado biome (Sick, 1997; Silva \& Bates, 2002). Duca et al. (2009) had firstly recorded Neothraupis fasciata as a host of Philornis, but the species was not identified. The authors also 
observed an average of $2.5 \%( \pm 1.9)$ of the causes of $N$. fasciata nestlings death in the nest to the parasitism of Philornis larvae. Also, for another sympatric tanager, the White-rumped Tanager (Cypsnagra hirundinacea), 15 nests had nestlings parasitized by Phylornis sp. larvae, but it did not cause any nest failure.

This paper records the third Philornis species to the Brazilian Cerrado and a new association with a bird host, Neothraupis fasciata. We discuss some biological data, provide characters to the recognition of $P$. torquans and present a key to the identification of Philornis species occurring in the Cerrado.

\section{MATERIAL AND METHODS}

\section{Study species}

The White-banded Tanager Neothraupis fasciata (Lichtenstein, 1823) (Passeriformes, Thraupidae) is endemic to South America, occurring in Suriname, Brazil, Bolivia, and Paraguay (Sick, 1997). Though N. fasciata is widespread in the Cerrado, its populations are declining moderately rapidly as a result of habitat loss and degradation for agricultural development and is considered currently "near threatened" (IUCN, 2017). Furthermore, models predict a $27-31 \%$ decline of its distributional range due to global warming (Marini et al., 2009a), and a low representation in reserves currently and in the future (Marini et al., 2009b).

\section{Data collection}

The flies specimens were collected at the Estação Ecológica Águas Emendadas (ESECAE), Distrito Federal, Brazil, a protected area in the Brazilian Cerrado, during a nesting monitoring program (Marini et al., 2012). Neothraupis fasciata is a common species in this reserve were it breeds during the wet season from September to January (Duca \& Marini, 2011), and where its biology has been studied in detail (Duca \& Marini, 2011, 2014a, b). The larvae and pupae were collected by one of authors (CD) from nestlings of $N$. fasciata during OctoberNovember 2003-2005 (Figs. 1-4). The larvae were intradermic in the nestlings and the pupae were collected
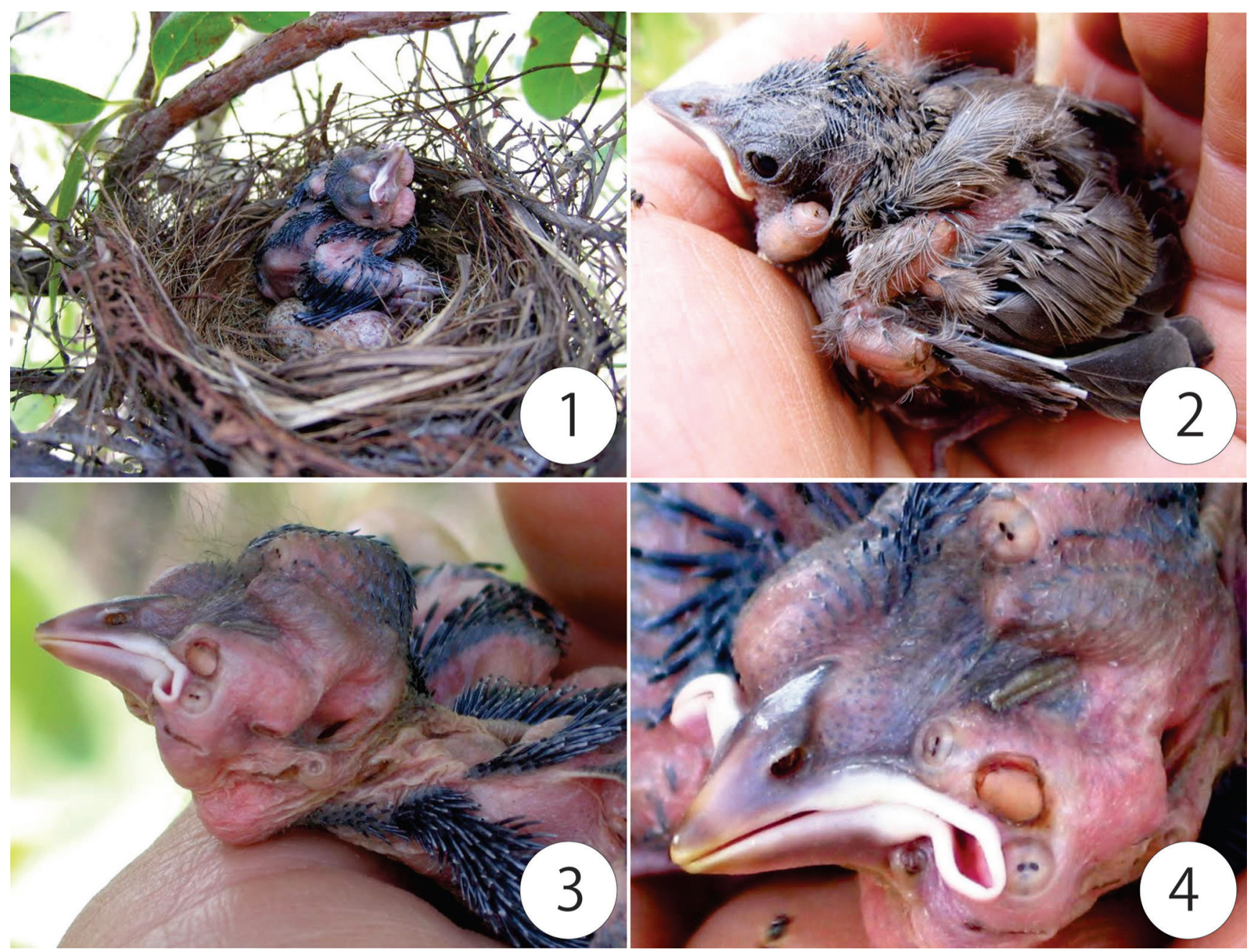

Figures 1-4. (1) Nest of Neothraupis fasciata (Lichtenstein), (Passeriformes, Thraupidae) with parasitized nestlings; (2) Nestling of Neothraupis fasciata (Lichtenstein), (Passeriformes, Thraupidae) parasitized with Philornis torquans (Nielsen) subcutaneous larvae; (3) Head (dorsal view) of a nestling of Neothraupis fasciata (Lichtenstein), (Passeriformes, Thraupidae) with parasitized with Philornis torquans (Nielsen) subcutaneous larvae; (4) Head (dorsal-lateral view) of a nestling of Neothraupis fasciata (Lichtenstein), (Passeriformes, Thraupidae) with parasitized with Philornis torquans (Nielsen) subcutaneous larvae. 
in the nests after the birds have abandoned them. The immatures collected were taken to the laboratory and reared under laboratory conditions until emergence The specimens ( 82 males and 82 females) were housed in the Coleção Entomológica do Departamento de Zoologia da Universidade de Brasília (DZUB), labeled: Brazil, Distrito Federal, Planaltina, Estação Ecológica de Águas Emendadas, Charles Duca col.: 30.xi.2003 (12 males, 13 females); 01.xii.2003 (9 males, 5 females); 02.xii.2003 (26 males, 22 females); 12.xi.2004 (15 males, 16 females, emerged in 13-21.xi.2004); 15.xi.2004 (7 males, 9 females); 16.xi.2004 (5 males, 2 females, emerged in 24-26.xi.2004); 31.x.2004 (8 males, 15 females, emerged in 01.xi.2004).

\section{Laboratory methods}

Male and female terminalia of Philornis were clarified in $\mathrm{KOH} 10 \%$ for 48 hours, immersed in glycerin on blades for dissection. Line drawings were made under optical microscope using a camera lucida. Digital images of the species were made using a Leica MZ16 stereomicroscope and the software program AutoMontage Pro by Syncroscopy, Version 5.03.0061. The terminology follows McAlpine (1981).

\section{RESULTS}

Philornis torquans can be recognized by the following combination of characters (Figs. 5-6): body length 6.5-7.0 mm; general color dark-brown with greyish pollinosity; width of frons at level of anterior ocellus 0.06-0.09 of head width in male and 0.19-0.22 in female; antenna and palpus yellow; cheek yellow haired; scutum with four vittae; halter yellow; legs yellow in male and brown in female; wing clear, sometimes with a faint brown mark on $r-m$ and sometimes also on dm-cu cross vein; abdomen brown with tergite 1 and 2 yellow; hind tibia variably curved in male with 4-6 anterodorsal setae and 2-3 anteroventral setae on middle third. Female with 2-3 anterodorsal setae on middle third. Larva intradermal. Puparium brown, posterior concavity deep, with rugose margins; spiracular slits "U or "V shaped (Dodge, 1968; Couri, 1999; Couri et al., 2009).

Male terminalia. Sternite 5 higher than wide with scattered setae on all disc (Fig. 7); cercal plate with anterior and posterior margins deep (Fig. 8); anterior margin of hypandrium sinuose, with two projections; aedeagal apodeme enlarged at apex (Fig. 9).

Female ovipositor and spermathecae as in Fig. 10.

\section{Key to Philornis adult species occurring in the Brazilian Cerrado}

1. Scutum yellowish brown . P. angustifrons (Loew)

1'. Scutum brown to dark brown with grayish pollinosity

2. Hind tibia with 2-4 anterodorsal setae on middle third legs yellow with darker tarsi in both sexes. P. deceptivus Dodge \& Aitken
2. Hind tibia with 4-6 anterodorsal setae in male and 2-3 in female; male hind tibia somewhat bowed; legs yellow in male and brown in female; calypter white with margin of upper one brown...... P. torquans (Nielsen)

\section{DISCUSSION}

The main cause of nest loss in N. fasciata was predation (Duca \& Marini, 2011), as expected for tropical birds (Marini, 2017). Other threats that affected reproduction were parasitism by Philornis sp on nestlings and brood parasitism by Molothrus bonariensis (Gmellin, 1789) (Passeriformes, Icteridae).

Philornis torquans was known to parasitize only seven hosts, whereas $P$. angustifrons and $P$. downsi have 28 and 27 hosts, respectively (Löwenberg-Neto, 2008). Other Thraupidae species also parasited by Philornis sp. include Ramphocelus carbo (with three Philornis species), Thraupis episcopus (with two), and Schistochlamys melanopis, Tachyphonus rufus and Thraupis palmarum (with one each) (Löwenberg-Neto, 2008), and Gubernatrix cristata (with one) (Domínguez et al., 2014).

Over the past decades larvae of Philornis species have been causing enormous damage to birds in South and Central America. In some regions, as the Galapagos
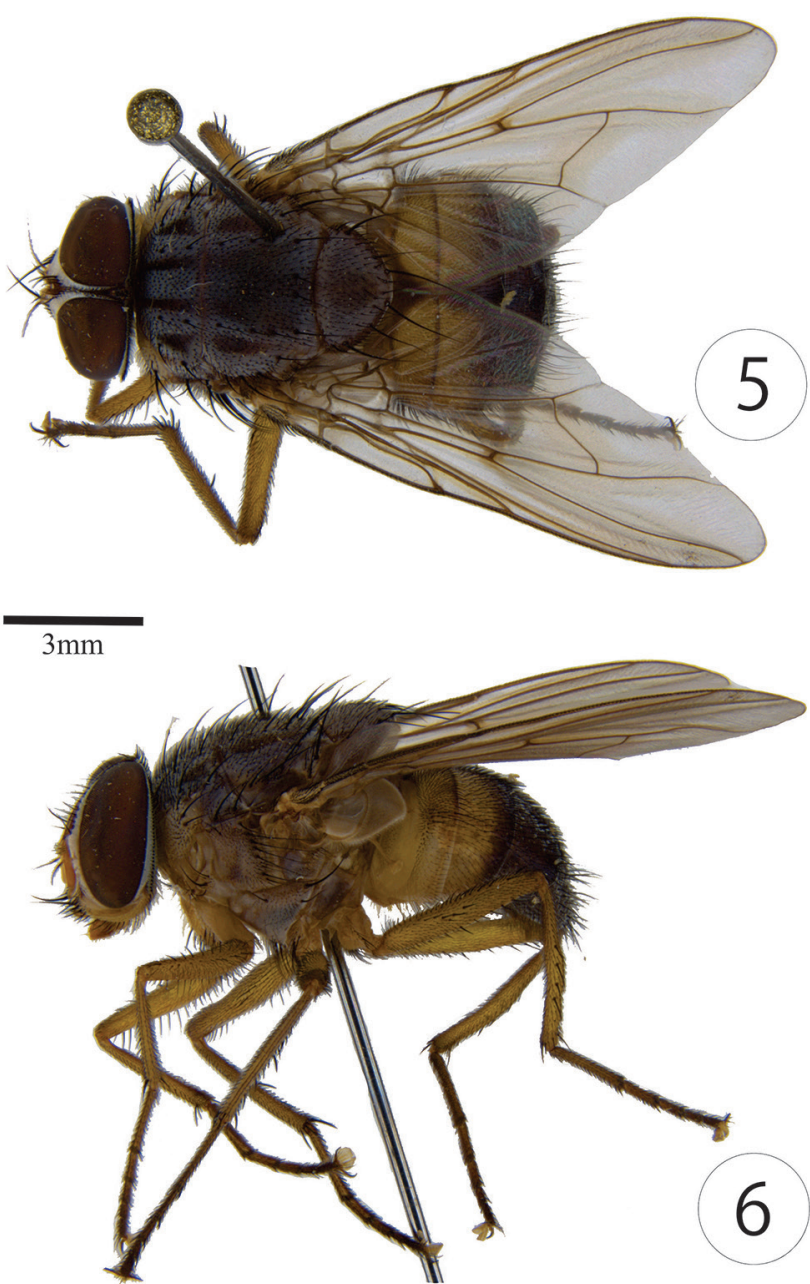

Figures 5-6. (5) Philornis torquans (Nielsen), adult male, dorsal view; (6) Philornis torquans (Nielsen), adult male, lateral view. 
Island, they are being incriminated as a major cause of the decline of wild bird populations (Luz et al., 2013). Philornis downsi, for example, was accidentally introduced in Galapagos and since then it has been the main cause of the decline of landbird species on the Galapagos Islands (Fessl et al., 2001). Because of this association, some bird species only found in the Galapagos are now threatened, including the Darwin's finches
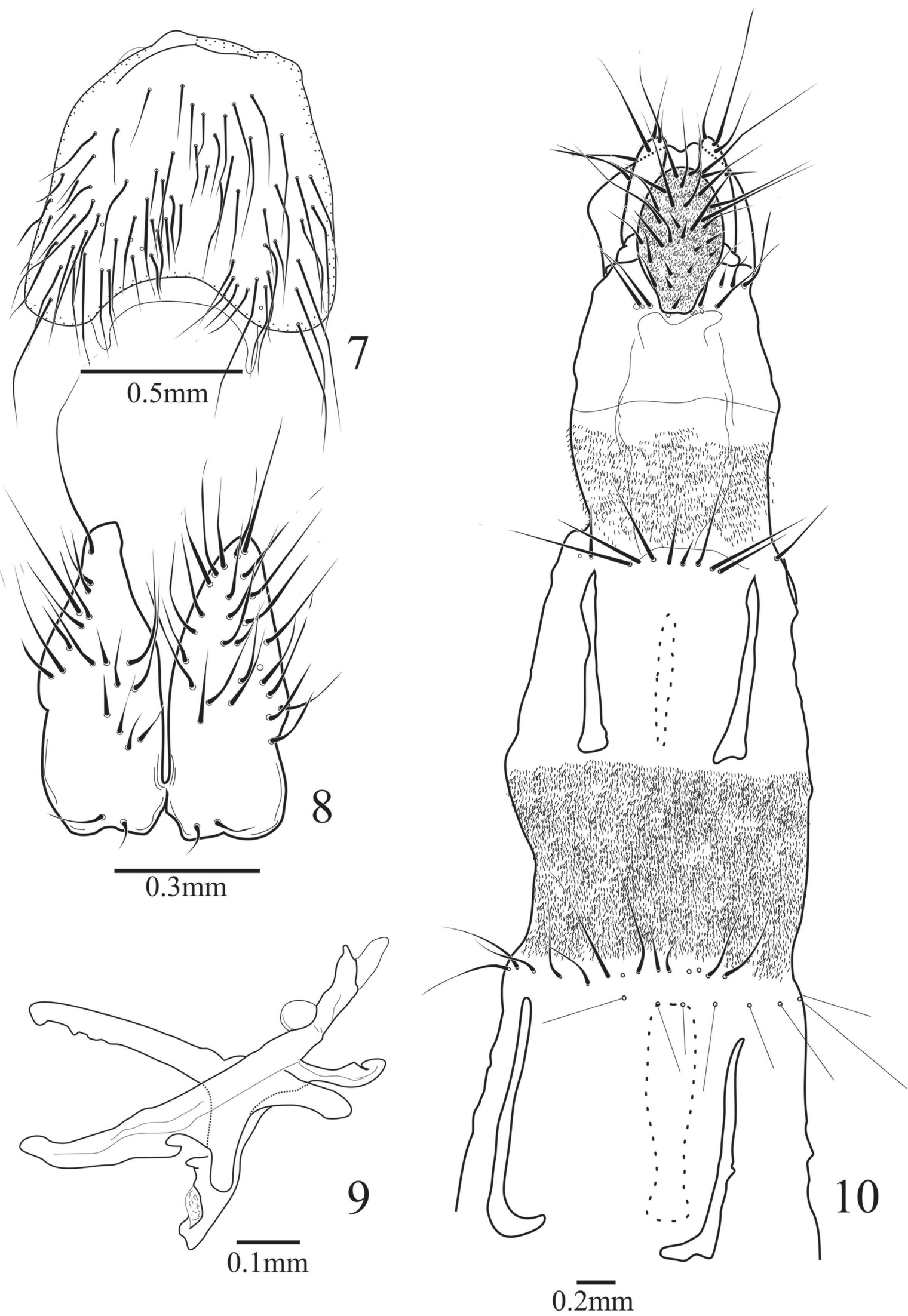

Figures 7-10. (7) Philornis torquans (Nielsen), sternite 5, dorsal view; (8) Philornis torquans (Nielsen), cercal plate, dorsal view; (9) Philornis torquans (Nielsen), aedeagal complex, lateral view; (10) Philornis torquans (Nielsen), ovipositor, dorsal and ventral view. 
(Passeriformes, Thraupidae) and the Mockingbirds (Passeriformes, Mimidae). Likewise, Argentina is giving particular attention to this problem, with several studies, including investigations on the effects of climate variability on the lifecycles of Philornis species and the impact on the health of their bird hosts (Couri et al., 2009; Antoniazzi et al., 2011; Silvestri et al., 2011; Manzoli et al., 2011). Considering this, information on the biology of Philornis species is essential to support control methods.

\section{ACKNOWLEDGMENTS}

This study was funded by grants from Conselho Nacional de Desenvolvimento Científico e Tecnológico (CNPq), Fundação de Amparo a Pesquisa do Rio de Janeiro (FAPERJ) and Fundação O Boticário de Proteção À Natureza. PEQUI - Pesquisa e Conservação do Cerrado provided institutional support. MSC, MAM and JRPL received a research fellowship from CNPQ.

\section{REFERENCES}

Antoniazzi, L.; Manzoli, D.; Rohrmann, D.; Saravia, M.; Silvestri, L. \& Beldomenico, P. 2011. Climate variability affects the impact of parasitic flies (Philornis torquans Nielsen 1913) on Argentinean forest birds. Journal of Zoology, 283: 126-134.

Bulgarella, M.; Quiroga, M.A.; Vera, G.A.B.; Dregni, J.S.; Cunninghame, F; Muñoz, D.A.M.; Monje, L.D.; Causton, C.E. \& Heimpel, G.E. 2015. Philornis downsi (Diptera: Muscidae), an avian nest parasite invasive to the Galápagos Islands, in Mainland Ecuador. Annals of the Entomological Society of America, 108(3): 242-250.

Carvalho, C.J.B. de; Couri, M.S.; Pont, A.C.; Pamplona, D. \& Lopes, S.M. 2005. A catalogue of the Muscidae (Diptera) of the Neotropical Region. Zootaxa, 860: 1-282.

Couri, M.S. 1984. Notes and descriptions of Philornis flies (Diptera, Muscidae, (yrtoneurininae). Revista Brasileira de Entomologia, 28, 473-490.

Couri, M.S. 1985. Considerações sobre as relações ecológicas das larvas de Philornis Meinert, 1890 (Diptera: Muscidae) com aves. Revista Brasileira de Entomologia, 29(1): 17-20.

Couri, M.S. 1999. Myiasis caused by obligatory parasites. Philornis Meinert (Muscidae):51-70. In: Guimarães, J.H. \& Papavero, N. Myiasis in man and animals in the Neotropical Region - bibliographic database. São Paulo, FAPESP, Editora Plêiade. 308 p.

Couri, M.; Antoniazzi, L.; Beldomenico, P. \& Quiroga, M. 2009. Argentine Philornis Meinert species (Diptera: Muscidae) with synonymic notes. Zootaxa, 2261: 52-62.

Dodge, H.R. 1968. Some new and little known species of Philornis (Diptera, Muscidae). Journal of Kansas Entomological Society, 41: 155-164.

Domínguez, M.; Reboreda, J.C. \& Mahler, B. 2014. Impact of shiny cowbird and botfly parasitism on the reproductive success of the globally endangered Yellow Cardinal Gubernatrix cristata. Bird Conservation International, 1-12.

Duca, C. \& Marini, M.Â. 2011. Variation in breeding of the Shrike-like Tanager in central Brazil. Wilson Journal of Ornithology, 123: 259-265.

Duca, C. \& Marini, M.Â. 2014a. Territorial system and adult dispersal in a cooperative-breeding tanager. Auk, 131: 32-40.
Duca, C. \& Marini, M.Â. 2014b. High survival and low fecundity of a neotropical savanna tanager. Emu, 114: 121-128.

Duca, C.; Yokomizo, H.; Marini, M.Â. \& Possingham, H.P. 2009. Cost-efficient conservation for the White-banded Tanager (Neothraupis fasciata) in the cerrado, central Brazil. Biological Conservation, 142: 563-574.

Dudaniec, R.Y. \& Kleindorfer, S. 2006. Effects of the parasitic flies of the genus Philornis (Diptera: Muscidae) on birds. Emu, 106, 13-20.

Fessl, B.; Couri, M.S. \& Tebbich, S. 2001. Philornis downsi Dodge \& Aitken, new to the Galapagos Islands, (Diptera, Muscidae).Studia Dipterologica, 8:317-322.

Higgins, B.F.; Lopes, L.E.;Santana, F.H.A.; Couri, M.S.\& Pujol-Luz, J.R. 2005. Sobre a ocorrência de Philornis angustifrons e P. deceptiva (Diptera: Muscidae) em ninhos de Suiriri affinis e S. islerorum (Aves, Tyrannidae), no cerrado do Distrito Federal, Brasil. Revista Entomologia y Vectores, 12(1): 127-131.

IUCN. 2017. The IUCN Red List of Threatened Species. Version 2017-3. http:// www.iucnredlist.org (July 19, 2018).

Löwenberg-Neto, P. 2008. The structure of the parasite host interactions between Philornis (Diptera: Muscidae) and neotropical birds. Journal of Tropical Ecology, 24: 575-580.

Luz, H.; Ferreira, I. \& Moyá-Borja, G.E. 2013. Efeito das moscas parasitas do gênero Philornis (Diptera, Muscidae) em Pitangus sulphuratus (Tyrannidae) no estado do Rio de Janeiro. Revista Brasileira de Medicina Veterinária, 35(2): 136-140.

Manzoli, D.; Antoniazzi, L. \& Beldomenico, P. 2011. Cambio ambiental global, parásitos y la salud de sus hospedadores: el ejemplo de moscas parásitas (Philornis spp.) de pichones en Argentina. Hornero, 26(1): 45-53.

Marini, M.Â. 2017. Nesting success of birds in fragmented forests from southeast Brazil. Revista Brasileira de Ornitologia, 25: 77-83.

Marini, M.Â.; Barbet-Massin, M.; Lopes, L.E. \& Jiguet, F. 2009a. Predicted climate-driven bird distribution changes and forecasted conservation conflicts in a neotropical savanna. Conservation Biology, 23: 1558-1567.

Marini, M.Â.; Barbet-Massin, M.; Lopes, L.E. \& Jiguet, F. 2009b. Major current and future gaps of Brazilian reserves to protect neotropical savanna birds. Biological Conservation, 142: 3039-3050.

Marini, M.Â.; Borges, F.J.A.; Lopes, L.E.; Sousa, N.O.M.; Gressler, D.T.; Santos, L.R.; Paiva, L.V.; Duca, C.; Manica, L.T.; Rodrigues, S.S.; França, L.F.; Costa, P.M.; França, L.C.; Heming, N.M.; Silveira, M.B.; Pereira, Z.P.; Lobo, Y.P.; Medeiros, R.C.S. \& Roper, J. 2012. Breeding biology of birds in the cerrado of central Brazil. Ornitologia Neotropical, 23: 385-405.

McAlpine, J.F. 1981. Morphology and terminology - adults. In: McAlpine, J.F.; Peterson, B.V.; Shewell, G.E.; Teskey, H.J.; Vockeroth, J.R. \& Wood, D.M. (Eds.). Manual of Nearctic Diptera. Ottawa, Agriculture Canada Research Branch. v.1, p. 9-63. (Monograph 27).

Mendonça, E.C. \& Couri, M.S. 1999. New associations between Philornis Meinert (Diptera, Muscidae) and Thamnophilidae (Aves, Passeriformes). Revista Brasileira de Zoologia, 16(4): 1223-1225.

Silvestri, L.J.; Antoniazzi, L.R.; Couri, M.S.; Monje, L.D. \& Beldomenico, P.M. 2011. First record of the avian ectoparasite Philornis downsi Dodge \& Aitken, 1968 (Diptera: Muscidae) in Argentina. Systematic Parasitology, 80(2): 137-140.

Sick, H. 1997. Ornitologia Brasileira. Rio de Janeiro, Nova Fronteira. 862 p.

Silva, J.M.C. \& Bates, J.M. 2002. Biogeographic patterns and conservation in the South American Cerrado: A tropical savanna Hotspot. BioScience, 52: 225-233.

Teixeira, D.M. 1999. Myiasis caused by obligatory parasites. 5b. General observations on the biology of species of the genus Philornis Meinert, 1890 (Diptera, Muscidae). In: Guimarães, J.H. \& Papavero, N. Myiasis in man and animals in the Neotropical region; Bibliographic database. Plêiade/FAPESP. p. 71-96. 